\title{
Impact of Perceived Brand Name Origin on Fashion Brand's Perceived Luxury
}

\section{Zoran Krupka, Durdana Ozretic-Dosen, Jozo Previsic}

Faculty of Economics and Business, University of Zagreb

J. F. Kennedy Square 6, 10000 Zagreb, Croatia

E-mail: zkrupka@efzg.hr,dozretic@efzg.hr,jprevisic@efzg.hr

\begin{abstract}
The aim of this paper is to investigate the impact of perceived brand name origin and perceived country of origin (COO) on fashion brand's perceived luxury. Results of exploratory research indicate that perceived brand name origin has a strong impact on perceived luxury, and subsequent willingness to pay a price premium, regardless whether the brand is fictional and only sounds as if originated from a certain country (e.g. "Italian sounding brand") or is a real brand. Results also indicate that by naming fashion brands to have a desirable (e.g. Italian) tone, potential negative impacts of real COO and even a country of manufacture (COM) could be mitigated.
\end{abstract}

Keywords: Brand Name Origin; Luxury Fashion Brands; Country of Origin; Fashion Marketing

\section{Introduction}

Luxury brand management has been a topic of interest to many scientists and practitioners during the last decade. That is not surprising because luxury sector has grown from a value of $\$ 20$ billion in 1985 [27] to its current over $€ 200$ (estimated \$260) billion worth and it is expected to grow 2-4 percents annually for the next two years [3]. Factors like growing globalization, development of digital and communication media, opportunities for easy money earning, countries like China and Russia opening for foreign brands, and cultural homogenization [8] have led to global success of numerous luxury brands, especially luxury fashion brands.

But not all countries have a pedigree for developing luxury brands. That is even more obvious in fashion where over 80 percent of all luxury brands originate from only a few countries [27]. Because of that, it is very important from which country the brand is perceived to originate. That leads us to another, very important factor in developing luxury fashion brands - Country-of-Origin construct (COO). 
Although, $\mathrm{COO}$ has been present in literature for over five decades, it is still topic of many current studies (e.g. [35], [5], [28]).

$\mathrm{COO}$ effect is one of several extrinsic attributes that potentially influence consumer attitudes towards a product [9]. Approximately one-quater of consumers make purchase decisions on the basis of COO information [23]. Another extrinsic attribute that influence consumers perception of product is definitely brand name. It has been suggested that the brand name cue evokes not only beliefs about the brand itself but also triggers recall of the country associated with it as its $\mathrm{COO}$ [19] and that both have broad and specific effects on consumer behavior [31].

Topics like country of origin and luxury brand management, lately even fashion marketing, are well studied, but there is still lack of research in the area of impact of brand name's perceived origin on perceived brand luxury. Although, there were some research that were pointed in that direction [2] [23], need for further understanding of this important issue still exists. In addition, most research was done in developed countries [6], thus omitting the understanding of developing countries which are opening up for luxury brands and thus becoming increasingly of interest to luxury brand marketers.

The question that this research aims to answer is whether it is possible, by selecting a brand name that is associated with desirable $\mathrm{COO}$, to affect the perceived brand's luxuriousness and to mitigate potentially negative impact of true $\mathrm{COO}$ and even a Country-of-Manufacture (COM).

\section{Literature Review}

\subsection{Luxury Fashion Brands}

Generally speaking, brand is a promise of performance to be delivered in return for the trust placed in a brand [37]. Thus brands embody the symbol, an implicit value proposition, and personality.

Luxury brands from an economics perspective can be defined as those whose ratio of functional utility to price is low while the ratio of intangible and situational utility to price is high [26]. From the product perspective, luxury brands are frequently defined in terms of their excellent quality, high transaction value and distinctiveness [16]. In addition to possible functional attributes, luxury brands are even more bought for their symbolic values arising from exclusivity, premium prices, image, status [18], premium quality across product lines, heritage of craftsmanship, recognizable style and design [7]. 
Level of brand's luxuriousness is "in the eye of the beholder", i.e. presents a perceptual category, influenced by cultural specificities [14]. While luxury products are often purchased simply because they cost more, without providing any additional direct utility over their cheaper counterparts [13], luxury brands may be used to enhance one's social status [22]. This is also implicit in the ideas of Christodoulides, Michaelidou and Li [11] who reported that the primary value of luxury brands is psychological, and that their consumption is dependent on a distinctive mix of social and individual cues.

As stated earlier, the luxury goods market is significant, not only in terms of its market value, but also in terms of its rate of growth [3] [16]. According to Seringhaus [34] France and Italy are the most important luxury brand source countries in the world. Those two countries command more than one-half of the global consumer luxury brands - Italy with 30 percent and France with 25 percent of the market. Taking into account fact that Gucci, Chanel, Dolce \& Gabbana, Cavalli, Armani, Yves Saint Laurent, and Lacroix are (just some of) Italian or French luxury brands, the share of luxury brands in fashion industry is expected to be even higher. The success around the world of items "Made in Italy" is mostly due to the Italian brand's ability to transfer a certain sense of product quality in concert with values and experiences of beauty, elegance, tradition, luxury, and life quality [36].

Brand's association with country of origin tends to have a strong impact on brand's reputation, especially in a specific industry such as fashion [26]. Piron [32] stated that a product's country of origin has a stronger effect when considering luxury products (i.e. higher monetary risk) than necessities. Thus, for luxury brands, especially for luxury fashion brands, COO presents a make-orbreak of brand's market success.

\subsection{Country of Origin and Luxury Brands}

Product's COO presents an important cue that consumers use to make their judgments and their subsequent purchase behaviors [29]. Importance of country of origin effect has mostly been discussed in the consumer behavior and international marketing literature (e.g., [25], [15]), while being relatively neglected in the brand management literature. Moreover, in consumer behavior literature, $\mathrm{COO}$ has been primarily analyzed as the real country of origin, while in brand management literature, it makes more sense to focus on the perceived $\mathrm{COO}$ and its impact on brand success [5]. Brand management literature has generally analyzed the impact of the actual $\mathrm{COO}$ on brand image (e.g. [1], [10]), but recent research on country of origin has shown that consumers often do not know the real origin of many (even of the well-known) brands [5].

Country of origin can be defined as an extrinsic product attribute indicating the country where a product was made, was assembled, or both [24]. This definition, 
although widely accepted, implies some operationalization difficulties. Thus, in this research we analyze the $\mathrm{COO}$ as the country in which corporate headquarters of the company marketing the brand is located, regardless of the place in which the brand in question is produced [4].

Consumers tend to recall the stored information about the brand and the country and then they relate the brand name with the $\mathrm{COO}$ to form a brand image and infer the product evaluation [21]. When a product's COO is known to consumers prior to exposure to the product's attributes, then the image of the country as a country of origin affects the brand's image. Because of that, it is very important to explore what is the impact of COO on perceptions of brand luxury so that companies know what strategy to apply (whether to emphasize country of origin or to depart from it).

When we consider fashion as industry, it is clear that some countries (e.g. Italy and France) tend to be perceived as countries that have an innate fashion capability [34]. Such perceptions provide companies from those countries a certain competitive advantage and privileges for building luxury brands in the fashion industry. Numerous aspects provide grounds for emphasizing countrybrand associations, and one of the most prominent is surely brand name which reflects country's cues [33].

\subsection{Brand Name Origin And Luxury Perceptions}

Thakor and Kohli [37] define brand-origin as the place, region, or country where brand is perceived to belong by its target consumers. Past studies suggested that brand name origin associations play potentially powerful role in the formation of brand attitudes [38] [30] [39] and that the brand name cue evokes not only beliefs about the brand itself but also triggers recall of the country associated with it as its country of origin [19].

Products with foreign brand names are frequently associated with the perceived $\mathrm{COO}$ of the brand [20]. Even in case of completely unfamiliar brands, consumers would develop some expectations and perceptions of that brand based on image of a country that seems to be associated to the brand name. Morover, literature recognizes [24] that countries are perceived to be experts in creating and producing certain product category (e.g. Japan and electronic products; USA and jeans; Germany and cars etc.). Because of that, COO image that those countries have for that exact product category is positive. So, many manufacturers and retailers use brand names that suggest origins different from the brands' real COO or COM and associate them with countries that have positive country of origin image for that product category. For example, Alba, a British manufacturer of electronic equipment, has introduced the Hinari brand, a name that does not convey the real origins of the product [4]. 
Literature has analyzed the role of real country of origin on consumer perceptions and brand name on consumer perceptions (e.g. [12]). However, this research aims at understanding how brand name itself can be a cue for perceived country of origin and thus generate positive brand associations. In that sense, we expect that the mere perceived origin of a brand name can transfer country-related beliefs to the brand.

Han [17] suggest that brand name may be even a more powerful summary construct than the COO. In that sense, brand name in itself implies existence of a powerful "story" linked to that brand, thus making country of origin effect less important in case of well-known brands. Moreover, if brand name is closely linked to (i.e. sounds as if it originates from) a certain country, we expect that the perceived $\mathrm{COO}$ resulting from that association will present a much stronger cue than possible cues arising from either real $\mathrm{COO}$ and/or COM associations [31].

Pecotich and Ward [31] suggested that country of origin or brand-origin operates in one of two ways. First, it may serve as a hallo effect to infer beliefs about attributes that make up the attitude towards a product or service, i.e. consumer evaluations of products and services are based on their perception of the country. And second, it may be used as a means of abstracting previous beliefs about attributes of products and services from a particular country into information called the summary construct.

Country of origin concept is still the topic of many current research projects (e.g. [5]) as it implies that brands would succeed by "nature" (i.e. by their COO) and not "nurture" (i.e. management that overturns potential negative COO effects). Although, topics like country of origin and fashion marketing, lately even luxury brand management, are well studied, there is lack of research in the area of impact of brand name's perceived origin on perceived brand luxury [33]. Even there was some research that has pointed in that direction (e.g. [2]), further research into nurturing brands to diminish possible negative $\mathrm{COO}$ effects is still needed.

\section{Research}

\subsection{Objective and Hypotheses}

The main purpose of this paper is to fill the gap in existing literature and research by investigating connection between perceptions of the country of origin given a brand name with perceived brand luxury in fashion marketing.

Based on the literature review, we propose two hypothesis:

H1: Perceived brand's COO has an impact on brand's perceived luxury.

$\mathrm{H} 2$ : If a brand name is associated with a desirable COO, the COM does not have an impact on perceived luxury. 


\subsection{Methodology}

This research presents a first step in our research project aiming to understand the complex relationship between brand's perceived and true country of origin, on one side, as well as the impact this relationship may have on brand's performance, leading to potential strong brand management implications (e.g. to brand luxury).

Data was collected on the sample of 276 younger consumers in Croatia. Each respondent filled out a questionnaire for 8 different brands, some of which were fictional (4 in total) and some real (4 in total) thus resulting in the total of 1808 data points after clearing out the dataset (deleting incomplete responses; 50 or $18.11 \%$ of returned questionnaires were incomplete).

Although having sample limited to young consumers presents a certain limitation, it is consistent with other research on related topics (e.g. [30]) and is only the first step in the overall research project. Moreover, Bain and Forsythe [8] reported that younger consumers represent current and important future market for luxury brands, they have knowledge about them and they are establishing life-long buying patterns and loyalties.

Given that real fashion luxury brand names are often personal names, fictional brand names were developed by randomly picking 20 different first-last names in France, Germany, Italy and USA from phonebooks. Further, a pretest was done on the sample of 8 experts in the fashion industry to rate which of the names seem the most probable brand names for luxurious fashion products. Questionnaire was pretested on a sample of 25 respondents.

\subsection{Results}

In terms of the demographic profiles of all 226 respondents, 171 or $75.66 \%$ were female and 55 respondents or $24.34 \%$ were male. Of all respondants, 89 of them $(39.38 \%)$ were between age of $18-21,102$ respondents $(45.13 \%)$ were between age of 22-25 and 35 respondents (15.49\%) were between 26-29 years old.

Dependent variable in this research was brand's perceived luxury which, for robustness reasons, was measured in three different ways: using an existing reflective scale, using a formative scale, and using a single-item measure of whether the brand is luxurious or not. Results were tested using the three different measures of the dependent variable and there were no significant differences between the models (see Table 1). Thus for simplicity reasons we present our results only with a reflective scale of perceived brand luxury. Moreover, as this is the first step in our research project, in the regressions we did not focus on control variables but on the main effects. 
Table 1

COO Impact on Perceived Brand Luxury (both fictional and real brands) - use of different scales for dependent variable

\begin{tabular}{lccc}
\hline & $\begin{array}{c}\text { Brand luxury } \\
\text { Formative scale }\end{array}$ & $\begin{array}{c}\text { Brand Luxury } \\
\text { Reflective scale }\end{array}$ & $\begin{array}{c}\text { Brand Luxury } \\
\text { Single Item }\end{array}$ \\
\hline COO_AUSTRIA &,$- 057^{*}$ &,$- 055^{*}$ &,$- 065^{*}$ \\
COO_BELGIUM &, 022 &, 024 &, 026 \\
COO_FRANCE &, $236^{* * *}$ &, $244 * * *$ &, $190^{* * *}$ \\
COO_GERMANY &,- 052 &,- 054 &,- 080 \\
COO_ITALY &, $246^{* * *}$ &, $239 * * *$ &, $226 * * *$ \\
COO_ISRAEL &,$- 053^{*}$ &,$- 047^{*}$ &,$- 061^{* *}$ \\
COO_CANADA &,$- 060^{*}$ &,$- 057^{*}$ &,- 042 \\
COO_NEITHERLANDS &,- 007 &,- 005 &,- 013 \\
COO_SPAIN &,- 012 &,- 013 &,- 025 \\
COO_SWISS &,$- 046^{*}$ &,$- 048^{*}$ &,$- 049 *$ \\
COO_UK &, 062 &, 069 &, 051 \\
COO_USA &, 037 &, 038 &, 010 \\
& & &, 100 \\
$\mathrm{R}^{2}$ &, 104 &, 105 & $16,643 * * *$ \\
$\mathrm{~F}$ & $17,394 * * *$ & $17,389 * * *$ & $* p<, 05 ; * * p<, 01 ; * * * p<, 001$
\end{tabular}

First we tested how familiar respondents were with the fictional brands. Results indicated that $12,9 \%$ believed they have heard of fictional brands while $87,1 \%$ did not. Also, average familiarity with fictional brands was 1,38 (on a 5 point scale), i.e. significantly below the theoretical mean of 3 ( $\mathrm{t}=-77,457$; sig=,000). Thus, selected brands were unfamiliar to customers. This implies that brand names were well chosen in the sense that they did not trick all the participants (e.g. what might have happened if we only altered the spelling of existing brands). However, they were good enough to "trick" $12,9 \%$ of participants to believe that they have heard of the brand before.

When fictional and real brands are jointly considered, results indicate that perceived $\mathrm{COO}$ has an impact on Perceived Brand Luxury $\left(\mathrm{R}^{2}=, 109\right)$ with brands originating from Italy $(\beta=, 239 ; \mathrm{p}<, 001)$ and France $(\beta=, 244 ; \mathrm{p}<, 001)$ having the strongest positive impact (see Table 2 ). When we consider only fictional brands the effect of perceived COO of provided brands is still significant. When only real brands are considered, the impact of perceived $\mathrm{COO}$ is even stronger.

These results indicate that $\mathrm{H} 1$ can be accepted and that perceptions of country of origin do influence the brand's perceived luxury, especially if perceived COO is Italy or France. Thus, even if luxury fashion brands are originating from countries other than Italy and France, they could benefit if their brand names are set to mimic Italian or French origin. 
Table 2

COO and COM Impact on Perceived Brand Luxury

\begin{tabular}{|c|c|c|c|c|c|c|}
\hline & \multicolumn{3}{|c|}{$\mathrm{COO}$} & \multicolumn{3}{|c|}{$\mathrm{COM}$} \\
\hline & All brands & Fictional & Real & All brands & Fictional & Real \\
\hline AUSTRIA &,$- 055^{*}$ &,- 046 & &,- 037 &,- 034 & \\
\hline BELGIUM &, 024 &, $056^{*}$ & &, 037 &, 042 & \\
\hline CHINA & & & &,- 003 &,- 074 &,- 076 \\
\hline $\mathrm{EU}$ & & & &,- 017 &,- 027 &,- 006 \\
\hline FRANCE &, $244 * * *$ &, $111^{*}$ &, $341^{*}$ &, $255^{*}$ & ,107 & ,289* \\
\hline GERMANY &,- 054 &,- 077 &, 070 &,- 016 &,$- 070 *$ & 071 \\
\hline INDIA & & & &,- 021 &,- 038 &, 042 \\
\hline INDONESIA & & & &,- 021 &,- 053 &,- 038 \\
\hline ITALY &, $239 * * *$ &, $147^{*}$ &, $342 *$ &, $256^{*}$ &, $100^{*}$ &, $281^{*}$ \\
\hline MEXICO & & & &,$- 052^{*}$ &,$- 064 *$ &,- 086 \\
\hline NEITHERLANDS &,- 004 & ,009 & & ,001 &, 014 & \\
\hline ROMANIA & & & &, 022 &,- 010 & ,029 \\
\hline SPAIN &,- 013 &,- 014 &, 050 &, 002 &,- 002 &, 044 \\
\hline TAIWAN & & & &,- 020 &,$- 067 *$ &,- 036 \\
\hline TURKEY & & & &, 010 &,$- 064 *$ &, 074 \\
\hline UK & ,069 &,- 006 &,- 092 &, 046 &,- 019 &,- 058 \\
\hline USA &, 038 &,- 038 &,- 038 &, $060^{*}$ &,- 018 &,- 020 \\
\hline VIETNAM & & & &, 021 &, 013 &,- 066 \\
\hline $\mathrm{R}^{2}$ & ,109 & ,067 &, 182 &, 119 & ,067 & ,189 \\
\hline $\mathrm{F}$ & 17,389 *** & $7,836^{* * * *}$ & $17,203 * * *$ & $10,391 * * *$ & $4,095^{* * *}$ & $5,517 * * *$ \\
\hline
\end{tabular}

Results regarding the COM indicate that brands perceived as produced in France $(\beta=, 255 ; \mathrm{p}<, 05)$, Italy $(\beta=, 256 ; \mathrm{p}<, 05)$ and USA $(\beta=, 060 ; \mathrm{p}<, 05)$ are perceived as more luxurious. When focusing on the real brands, the same holds true only for France and Italy with no negative impacts on perceived luxury of where the wellknown luxury brands are actually produced.

When we focus on the fictional brands, there is a positive impact only of Italy as COM, while fictional brands perceived as produced in other countries exhibit either negative (Germany, Mexico, Taiwan, Turkey) or non significant impact (see Table 2). This could be since these countries are generally not linked to high fashion industry.

In this respect, we were expecting that China as the country of manufacture would diminish positive country of origin effects on brand's perceived luxury. However, contrary to what is often believed, China as COM has no significant impact on the perceived brand luxury. Such results might imply that consumers have gotten used to the idea that fashion products tend to be produced in China and thus believe that Chinese production has achieved a level of quality that is acceptable and/or they accept that fashion products tend to be produced in countries like China. 
When we analyze the impact of perceived COM, depending on the fictional brand's perceived $\mathrm{COO}$, results indicate that there is no effect of country of manufacture only for brands that are believed to originate from Italy (see Table 3).

One possible explanation is that Italian luxury brands stress their design while brands originating from countries like USA, France and Germany communicate their quality. In that sense, if perceived country of origin is Italy, then consumers still recognize the luxury stemming from the design, while they might have a problem accepting that high quality German brand is produced abroad.

Thus, $\mathrm{H} 2$ is partially accepted. If perceived COO is so strongly linked to luxury (like in the case of Italy), it does not matter where the product is actually originating from or manufactured. However, if perceived country of origin is not so strongly linked to luxury, COM exhibits significance. Further research is planned in order to understand the mechanism between different facets of luxury (e.g. luxury grounded on design, quality, etc).

Table 3

COM Impact on Brand's Perceived Luxury if a fictional brand is perceived to originate from Italy, France, Germany, USA

\begin{tabular}{|c|c|c|c|c|}
\hline & $\begin{array}{c}\text { Fictional } \\
\text { Italian }\end{array}$ & $\begin{array}{l}\text { Fictional } \\
\text { French }\end{array}$ & $\begin{array}{c}\text { Fictional } \\
\text { German }\end{array}$ & $\begin{array}{c}\text { Fictional } \\
\text { USA }\end{array}$ \\
\hline COM_AUSTRIA & & & ,001 & \\
\hline COM_BULGARIA & &,- 034 &, $156^{*}$ & \\
\hline COM_CAMBODIA &,- 020 &,- 049 & ,006 &,$- 201 *$ \\
\hline COM_CHINA &,- 041 &,- 179 &,$- 270 *$ &,- 179 \\
\hline COM_EU & &,- 065 &,- 033 & \\
\hline COM_GERMANY & & &,- 178 & \\
\hline COM_FRANCE & &,- 037 & & \\
\hline COM_INDIA &,- 028 &,$- 152 *$ &,- 061 &,- 041 \\
\hline COM_INDONESIA &,- 008 &, 021 &,$- 145^{*}$ &,- 100 \\
\hline COM_ITALY & ,004 & ,136* & & \\
\hline COM_MEXICO & & & &,- 121 \\
\hline COM_POLAND & &,- 002 &,$- 130 *$ & \\
\hline COM_ROMANIA & ,014 & ,019 &,- 089 & \\
\hline COM_TAIWAN & ,012 &,$- 156^{*}$ &,- 090 &,$- 150 *$ \\
\hline COM_THAILAND &,- 006 &,$- 163^{*}$ &,- 074 & ,091 \\
\hline COM_TURKEY &,- 094 &,- 095 &,$- 159 *$ & \\
\hline COM_UK & & & &,- 008 \\
\hline COM_USA & &,- 058 &,- 017 &,- 050 \\
\hline COM_VIETNAM & 067 &,- 026 & ,022 &,- 068 \\
\hline $\mathrm{R}^{2}$ & ,017 &, 114 & , 103 & 097 \\
\hline $\mathrm{F}$ &, 521 & $2,087 *$ & $1,774 *$ & $2,200 *$ \\
\hline
\end{tabular}


When results for real luxury fashion brands are considered (Table 4), controlling for the perceived $\mathrm{COO}$, there is no significant negative impact of $\mathrm{COM}$ on the perceived luxury. This is logical since consumers, if they know the brand, they evaluate the brand image and do not need other cues to make expectations about brand characteristics.

Table 4

COM Impact on Brand's Perceived Luxury if a real brand is perceived to originate from Italy, France, Germany, USA

\begin{tabular}{|c|c|c|c|c|}
\hline & Real Italian & $\begin{array}{l}\text { Real } \\
\text { French }\end{array}$ & $\begin{array}{c}\text { Real } \\
\text { German }\end{array}$ & Real USA \\
\hline COM_AUSTRIA & & & & \\
\hline COM_BULGARIA & & ,044 & & \\
\hline COM_CAMBODIA & & & & \\
\hline COM_CHINA & ,298 & 085 & ,200 &,- 075 \\
\hline COM_EU & & & & 009 \\
\hline COM_GERMANY & & & ,491 & \\
\hline COM_FRANCE & & ,335 & & \\
\hline COM_INDIA & & ,097 & & \\
\hline COM_INDONESIA & , 168 & & &,- 137 \\
\hline COM_ITALY &, $585 *$ & & & \\
\hline COM_MEXICO & & & &,- 163 \\
\hline COM_POLAND & & ,097 &,- 109 & \\
\hline COM_ROMANIA &, 059 & & & \\
\hline COM_TAIWAN & ,117 & ,036 & ,256 &,- 168 \\
\hline COM_THAILAND & , 112 & 045 & &, 152 \\
\hline COM_TURKEY & ,359 &,- 017 & & ,012 \\
\hline COM_UK & & & & \\
\hline COM_USA & & ,097 & &, 058 \\
\hline COM_VIETNAM & &,- 104 & & ,036 \\
\hline $\mathrm{R}^{2}$ & 077 & , 101 & , 167 &, 115 \\
\hline $\mathrm{F}$ & 1,522 & 1,324 & 1,305 & 1,181 \\
\hline
\end{tabular}

In addition, we have offered respondents 24 pairs of brands (real and/or fictional) used in a questionnaire and asked them for each pair to chose what brand would they buy. In each pair countries of origin of the brands were different.

When looking at the results for real brands paired together, in most cases Italian brands were chosen as ones that respondents would buy, followed by French, USA and German brands. When looking at pairs of fictional brands results are similar. Most respondent chosen Italian sounding brands, then French, USA and German sounding brands. 
Results for pairs consist of real and fictional brands show that in most cases $(89.38 \%)$ respondents would chose real brands over fictional ones. However, in $11.62 \%$ of cases respondents have chosen fictional over real brands. Their choices were mostly made in favor of Italian sounding fictional brand. That also imply that $\mathrm{COO}$ or at least perceived $\mathrm{COO}$ influence fashion brand's perceived luxury and consumers willingness to buy brands from certain country.

\subsection{Limitation}

The main limitation of this research is related to the sample. For this reasearch we have used a convenient sample od younger respondents, and therefore findings cannot be generalizable. However, a lot of research in luxury branding field (e.g. [8], [30]) have been made on convenient sample of younger consumers as there is no reason to expect systematic differences, other than disposable income role.

In addition, since the focus of our paper is on understanding the perceived brand name origin on fashion brand's perceived luxury, having younger consumers with no (or with limited) experience with such brands is actually beneficial. Such respondents will not be biased by performance of those brands but will base their perceptions only on expectations.

\section{Conclusions}

Brand management is of constant interest of both academics and practitioners. Fashion marketing and especially luxury brand management have become a hot topic lately because of sales volume achieved and growth potential even in the time of crises.

Brand naming is of great importance for luxury fashion brand management. Based on a brand name, consumers create brand expectations and perceptions. In the lack of other cues, brand's country of origin presents an important cue for making expectations on brand's luxury. Regarding this initial research into impact of perceived brand name origin and $\mathrm{COO}$ on fashion brand's perceived luxury, the mere name association to Italy or France as a country of origin makes the consumer perceive the brand as more luxurious.

In addition, we have also analyzed the impact of perceived country of origin on price premium consumers are willing to pay for the brand. And again the results indicate that Italian and French sounding brands can automatically expect consumers to be willing to pay a price premium.

Also, interesting conclusion is that potential negative impacts of country of manufacture could be mitigated by naming fashion brands to sound as if they are originating from a desirable and favorable country.

Although this research fills some of the gaps in the literature, there is still need for further research in this area. First of all, it would be beneficial to use 
representative sample so that data and conclusions could be generalizable. One of possible directions for the future research would be to understand the mechanism between different facets of luxury (e.g. luxury grounded on design, quality, etc). As it is noticed in the business, many fashion industry companies that originate from emerging countries that do not have positive COO (like China) begun to manufacture in countries that do have positive country of origin for luxury fashion (like Italy) simply to ensure that they could use the "Manufacture in (e.g.) Italy" label to enhance favorable associations toward the brands and mitigate unfavorable $\mathrm{COO}$ associations [23]. So, in the future research more attention should be given to the impact of country of manufacture on perceived luxury.

\section{References}

[1] Ahmed, S. A., d'Astous, A. (1996). Country of Origin and Brand Effects: a Multi-Dimensional and Multi-Attribute Study. Journal of International Consumer Marketing, 9 (2), 93-115

[2] Aiello, G., Donovito, R., Godey, B., Pederzoli, D., Wiedmann, K-P., Hennings, N., Siebels, A., Chan, P., Tsuchiya, J., Rabino, S., Ivanova, S. I., Weitz, B., Oh, H., Singh, R. (2009). An International Perspective on Luxury Brand and Country-of-Origin Effect. Brand Management, 16 (5/6), 323-337

[3] Bain and Company, www.bain.com (November 2012)

[4] Balabanis, G., Diamantopoulos, A. (2008). Brand Origin Identification by Consumers: A Classification Perspective. Journal of International Marketing, 16 (1), 39-71

[5] Balabanis, G., Diamantopoulos, A. (2011). Gains and Losses from the Misperception of Brand Origin: The Role of Brand Strength and Countryof-Origin Image. Journal of International Marketing, 19 (2), 95-116

[6] Batra, R., Ramaswamy, V., Alden, D. L., Steenkamp, J-B.E.M., Ramachander, S. (2000). Effects of Brand Local and Nonlocal Origin on Consumer Attitudes in Developing Countries. Journal of Consumer Psychology, 9 (2), 83-95

[7] Beverland, M. (2006). The 'Real Thing': Branding Authenticity in the Luxury Wine Trade. Journal of Business Research, 59 (2), 251-258

[8] Bian, Q., Forsythe, S. (2012). Purchase Intention for Luxury Brands: A Cross Cultural Comparison. Journal of Business Research, 65, 1443-1451

[9] Bilkey, W., Nes, E. (1982). Country of Origin Effects on Product Evaluations. Journal of International Business Studies, 13, 89-99

[10] Cervino, J., Sanchez, J., Cubillo, J. M. (2005). Made in Effect, Competitive Marketing Strategy and Brand Performance: an Empirical Analysis for Spanish Brands. Journal of American Academy of Business, 6 (2), 237-243 
[11] Christodoulides, G., Michaelidou, N., Li, C. H. (2009). Measuring Perceived Brand Luxury: An Evaluation of the BLI Scale. Brand Management, 16 (5/6), 395-405

[12] D'Astous, A., Ahmad, A. S. (1999). The Importance of the Country Images in the Formation of the 'Consumer Product Perceptions. International Marketing Review, 16 (2), 108-125

[13] Dubois, B., Duquesne, P. (1993). The Market for Luxury Goods: Income versus Culture. European Journal of Marketing, 27, 35-44

[14] Eng, T-Y., Bogaert, J. (2010). Psychological and Cultural Insights into Consumption of Luxury Western Brands in India. Journal of Customer Behaviour, 9 (1), 55-75

[15] Erickson, G. M., Johansson, J. K., Chao, P. (1984). Image Variables in Multi-Attribute Product Evaluations: Country-of-Origin Effects. Journal of Consumer Research, 11, 694-669

[16] Fionda, A. M., Moore, C. M. (2009). The Anatomy of the Luxury Fashion Brand. Brand Management, 16 (5/6), 347-363

[17] Han, C. M. (1989). Country Image: Halo or Summary Construct?. Journal of Marketing Research, 24, 222-229

[18] Jackson, T. B. (2004). International Retail Marketing. Oxford: Elsevier Butterworth-Heinemann

[19] Khan, H., Bamber, D. (2008). Country of Origin Effects, Brand Image, and Social Status in an Emerging Market. Human Factors and Ergonomics in Manufacturing, 18 (5), 580-588

[20] Kinra, N. (2006). The Effect of Country-of-Origin in Foreign Brand Names in the Indian Market. Marketing Intelligence \& Planning, 24 (1), 15-30

[21] Koubaa, Y. (2008). Country of Origin, Brand Image Perception, and Brand Image Structure. Asia Pacific Journal of Marketing and Logistics, 20 (2), $139-155$

[22] Mandel, N., Petrova, P. K., Cialdini, R. B. (2006). Images of Success and the Preference for Luxury Brands. Journal of Consumer Psychology, 16 (1), 57-69

[23] Melnyk, V., Klein, K., Völckner, F. (2012). The Double-eged Sword of Foreign Brand Names for Companies from Emerging Countries. Journal of Marketing, 76, 21-37

[24] Meng, J., Nasco, S. A., Clark, T. (2007). Measuring Country-of-Origin Effects in Caucasians, African-Americans and Chinese Consumers for Products and Services. Journal of International Consumer Marketing, 20 (2), 17-31 
[25] Nagashima, A. (1970). A Comparison of Japanese and U.S. Attitudes toward Foreign Products. Journal of Marketing, 34, 68-74

[26] Nueno, J. L., Quelch, J. A. (1998). The Mass Marketing of Luxury. Business Horizons, November/December, 61-68

[27] Okonkwo, U. (2009). The Luxury Brand Strategy Challenge. Journal of Brand Management, 16, 287-289

[28] Ozretic-Dosen, D., Skare, V., Krupka, Z. (2007). Assessments of Country of Origin and Brand Cues in Evaluating a Croatian, Western and Eastern European Food Product. Journal of Business Research, 60 (2), 130-136

[29] Pappu, R., Quester, P. G., Cooksey, R. W. (2006). Consumer-based Brand Equity and Country-of-Origin Relationships: Some Empirical Evidence. European Journal of Marketing, 40 (5/6), 696-717

[30] Park, H-J., Rabolt, N. J., Jeon, K. S. (2008). Purchasing Global Luxury Brands among Young Korean Consumers. Journal of Fashion Marketing and Management, 12, 244-259

[31] Pecotich, A., Ward, S. (2007). Global Branding, Country of Origin and Expertise: An Experimental Evaluation. International Marketing Review, 24 (3), 271-296

[32] Piron, F. (2000). Consumers' Perceptions of the Country-of-Origin Effect on Purchasing Intentions of (In)Conspicuous Products. Journal of Consumer Marketing, 17 (4), 308-325

[33] Salciuviene, L., Ghauri, P. N., Streder, R. S., de Mattos, C. (2010). Do Brand Names in a Foreign Language Lead to Different Brand Perceptions? Journal of International Marketing, 26 (11/12), 1037-1056

[34] Seringhaus, F. H. R. (2005). Comparison of Website Usage of French and Italian Luxury Brands. Journal of Euromarketing, 14 (4), 5-34

[35] Shukla, P. (2012). The Influence of Value Perceptions on Luxury Purchase Intentions in Developed and Emerging Markets. International Marketing Review, 29 (6), 574-596

[36] Snaiderbaur, S. (2009). Made in Italy"' in China: From Country of Origin to Country Concept Branding. Journal of Brand Management, 4 (3/4), 63-74

[37] Thakor, M. V., Kohli, C. S . (1996). Brand Origin: Conceptualization and Review. Journal of Consumer Marketing, 13 (3), 27-42

[38] Thakor, M. V., Lavack, A. N. (2003). Effect of Perceived Origin Associations on Consumer Perceptions of Quality. The Journal of Product and Brand Management, 12 (6/7), 394-407

[39] Truong, Y., Simmons, G., McColl, R., Kitchen, P. J. (2008). Status and Conspicuousness - Are They Related? Strategic Marketing Implications for Luxury Brands. Journal of Strategic Marketing, 16 (3), 189-203 